\title{
Pengembangan Materi Ajar Bahasa Inggris Berbasis Youtube Dengan Memanfaatkan Aplikasi Edit Kinemaster Dan Power Point Untuk Mahasiswa Di Luar Prodi Bahasa Inggris UNJA
}

\author{
Nely Arif, dan Duti Volya \\ Dosen FKIP, Universitas Jambi
}

\begin{abstract}
ABSTRAK
Tujuan dari penelitian ini adalah untuk mengembangkan Materi ajar Bahasa Inggris Berbasis YouTube dengan Memanfaatkan Aplikasi Edit Kinemaster dan PowerPoint untuk Mahasiswa di Luar Prodi Bahasa Inggris Unja. Jadi, materi ajar yang dihasilkan adalah dalam bentuk digital yang bisa diakses oleh mahasiswa dan siapapun melalui YouTube. Sebelum diupload, tentunya meteri itu dirancang atau dibuat dengan memanfaatkan aplikasi power point dan edit Kinemaster. Jenis penelitian ini adalah penelitian pengembangan yang sering juga disebut penelitian dan pengembangan (Research and Development). Penelitian pengembangan ini dilakukan dengan memakai kerangka A-D-D-I-E (Analysis, Design, Development, Implementation and Evaluation). Namun tidak semua tahapan ADDIE ini akan dilaksanakan karena keterbatasan waktu. Kali ini penelitian akan sampai pada tahap pengembangan saja yakni berupa prototipe produk yang berupa YouTube yang sudah divalidasi oleh ahli. Untuk mengetahui kebutuhan mahasiswa dalam mata kuliah Bahasa Inggris di luar prody Bahasa Inggris, peneliti telah melakukan penyebaran angket kuesioner kepada mahasiswa yang mengontrak mata kuliah Bahasa inggris yang diajar oleh peneliti. Angket ini disebarkan secara online dalam bentuk google form kepada 35 mahasiswa yang menjadi responden. 35 mahasiswa tersebut berasal dari 1 kelas yang ada di Fakultas Ekonomi Unja. Ada 14 video yang dihasilkan. Diantara topik pembahasan di video tersebut adalah Subjek dalam Bahasa Inggris, Tobe dalam Bahasa Inggris, dan I am Doing (Present Continous Tense).
\end{abstract}

Kata Kunci: Materi ajar, Bahasa Inggris, Youtube

\section{PENDAHULUAN}

Mata kuliah (MK) Bahasa Inggris untuk mahasiswa di luar prodi bahasa Inggris Unja merupakan mata kuliah wajib universitas. Artinya semua mahasiswa dari apapun jurusan dan fakultasnya, wajib mengambil mata kuliah ini sebelum mereka tamat. Untuk saat ini, mata kuliah ini diampu oleh dosen bahasa Inggris FKIP Unja. Kemudian mengingat kedudukan mata kuliah Bahasa Inggris sebagai pendukung mata kuliah lainnya, maka MK ini hanya diajar dalam 1 semester saja. Oleh karena itu, pentinglah kiranya dosen pengampu mata kuliah ini untuk lebih kreatif agar setelah mahasiswa yang diajarkan nanti tidak lagi kuliah di kelas, mereka tetap bisa mempelajari kembali materi bahasa Inggris yang pernah dipelajari di luar kelas. Apalagi di zaman yang serba maju dan berteknologi tinggi dewasa ini, kalau pengajar tidak bisa beradaptasi dengan perkembangan yang ada, mereka akan tertinggal jauh baik secara kualitas dan kuantitas. Salah satu caranya yang peneliti anggap cukup ngehit atau ngetrend adalah dengan menggunakan media YOUTUBE. Penggunaan media YouTube dalam pembelajaran merupakan bentuk langkah yang peneliti anggap sebagai sesuatu yang positif dan menantang. Di sini dituntut kreativitas penggunanya dalam meramu konten yang menarik dan bersaing di dunia yang serba digital ini. 
Sejauh yang peneliti amati belum ada satu pun dosen bahasa Inggris Unja, terutama yang mengampu MK Bahasa Inggris sebagai MK umum atau wajib universitas membuat materi ajar bahasa Inggris khusus untuk mahasiswa non pendidikan bahasa Inggris yang diunggah ke media YOUTUBE . Padahal media ini menurut hemat peneliti adalah salah satu media modern dan kekinian yang bisa menjangkau seluruh lapisan masyarakat mengingat akses internet sudah dimana-mana bahkan sempai ke pelosok desa. Dengan mengunggah materi ajar bahasa Inggris, tidak hanya mahasiswa yang menjadi target dari pembuatan materi ini saja yang bisa mendapat manfaat, tetapi orang lain yang berminat dalam hal yang sama juga bisa.

Selanjutnya kalau ditelusuri lebih jauh materi atau bahan ajar merupakan salah satu aspek yang sangat berpengaruh dalam berhasil tidaknya suatu pembelajaran apabila disusun secara sistematis dan terorganisir. Seperti yang ditulis oleh Volya dan Arif (2017:1) yaitu dalam upaya membuat pengajaran yang bermakna, seorang pengajar selayaknya dapat menganalisa sistematika pengajaran. Materi ajar sebagai salah satu aspek yang mempengaruhi kesuksesan pembelajaran dapat digunakan dalam mencapai tujuan pembelajaran.

Selanjutnya, untuk bisa menghasilkan penyajian materi pembelajaran yang baik, penggunaan power point masih yang dapat diandalkan sampai saat ini. Itu jikalau kita menyajikannya secara langsung seperti di kelas, seminar dan sebagainya. Jadi jangkauannya menurut hemat peneliti sangat terbatas. Akan lain halnya jika materi dalam bentuk power point dijadikan sebuah video yang kemudian diunggah ke YouTube seperti yang banyak dilakukan oleh Content Youtube Creator yang ada sekarang, tentu akan menjadi sesuatu yang lebih spesial karena bisa menjangkau banyak lapisan masyarakat sejalan dengan perkembangan di dunia teknologi informasi. Nah, untuk menghasilkan video yang berkualitas, maka diperlukan aplikasi edit video. Dari sekian aplikasi edit video yang pernah peneliti pakai, Kinemaster adalah salah satu yang terbaik.

Berdasarkan penjelasan di atas, peneliti mengembangkan Materi Ajar Bahasa Inggris Berbasis YouTube dengan Memanfaatkan Aplikasi Edit Kinemaster dan PowerPoint untuk Mahasiswa di Luar Prodi Bahasa Inggris Unja. Dengan demikian diharapkan proses pembelajaran kedepannya bisa lebih bermakna serta menyenangkan.

\section{Penelitian Yang Relevan}

Pertama adalah penelitian yang dilakukan oleh Dewi dan Carniasih (2018). Mereka melakukan penelitian berkaitan dengan pembelajaran bahasa Inggris dan YouTube. Penelitian ini bertujuan untuk menganalisa pengaruh media pembelajaran berbasis YouTube dalam pembelajaran tata bahasa Inggris dalam usaha memberi kesempatan siswauntuk belajar dengan cara yang lebih menarik. Data dikumpulkan melalui teknik observasi dan penyebaran angket kepada responden kelompok mahasiswa semester empat dalam mata kuliah Grammar and Usage 2. Hasil dari penelitian menunjukkan bahwa video youtube bisa digunakan sebagai sebuah media pembelajaran Grammar and Usage 2 yang mendapat persepsi positif dari mahasiswa.

Yang kedua adalah penelitian yang dilakukan Wigati, dkk. (Tanpa Tahun) Tujuannya adalah mengembangkan YouTube untuk pembelajaran berbasis Ki Hadjar Dewantara pada materi Integral di SMA dan mengetahui tingkat kelayakan YouTube yang dibuat untuk pembelajaran berbasis KiHadjar Dewantara pada materi Integral di SMA. Produk yang dibuat berupa multimedia pembelajaran dengan judul "Pengembangan YoutubePembelajaran Berbasis Ki Hadjar Dewantara untuk Materi Integral di SMA”. Materi yang dibahas dalam media pembelajaran adalah integral. Media pembelajaran yang dibuat dilengkapi dengan 
materi, video, evaluasi sebagai pendukung dalam memahami konsep materi dan disajikan menggunakan bahasa Indonesia yang dikemas dalam bentuk YouTube

Kedua penelitian di atas memiliki persamaan dengan penelitian yang dilakukan ini yaitu sama-sama menggunakan YouTube sebagai basis dalam pembelajaran. Di sisi lain dapat dikemukan bahwa penelitian yang pertama dan yang dilakukan sama-sama menjadikan bahasa Inggris sebagai target pembelajaran. Sedangkan yang kedua persamaannya adalah pada jenis penelitiannya yakni sama-sama pengembangan. Namun target pembelajarannya adalah Sejarah di SMA. Sedangkan yang akan dilakukan adalah di level perguruan tinggi.

\section{METODOLOGI PENELITIAN}

Adapun perihal yang akan dibicarakan dalam bab tiga ini adalah rancangan dan prosedur penelitian, data dan sumber data teknik pengumpulan data dan analisis data.

\section{Rancangan Penelitian}

Jenis penelitian ini adalah penelitian pengembangan yang sering juga disebut penelitian dan pengembangan (Research and Development). Rusdi (2018:19) merangkum istilah penelitian pengembangan dari berbagai literature sebagai berikut. 1. Penelitian Desain (design Studies)

2. Penelitian Pengembangan (Development Research)

3. Penelitian Desain dan Pengembangan (design and Development Research)

4. Penelitian Rekayasa (engineering Research)

5. Penelitian Formatif (Formatif Research)

Dari berbagai istilah tersebut Rusdi (2018:19) memilih memakai istilah penelitian desain dan pengembangan dikarenakan didalamnya sudah terkandung makna dari istilah yang ada lainnya seperti merancang, rekayasa, pengujian dan evaluasi formatif.

Selanjutnya Borg dan Gall (1983:772) dalam latief mendefenisikan penelitian pengembangan sebagai sebuah proses yang digunakan untuk mengembangkan dan memvalidasi produk pendidikan. Jadi penelitian yang akan dilakukan ini akan dihasilkan suatu produk non-cetak berupa materi ajar video YouTube. Sedangkan Subjek penelitian pengembangan ini adalah mahasiswa di luar prodi bahasa Inggris yang pernah diajar peneliti seperti di Fakultas Kehutanan Sainteks dan Ekonomi.

\section{Prosedur Penelitian}

Penelitian pengembangan ini dilakukan dengan memakai kerangka A-D-D-I-E (Analysis, Design, Development, Implementation and Evaluation). Namun tidak semua tahapan ADDIE ini dilaksanakan karena keterbatasan waktu. Kali ini penelitian sampai pada tahap pengembangan saja yakni berupa prototipe produk yang berupa Video YouTube yang sudah divalidasi oleh ahli. Sedangkan tahap Implementation dan Evaluation direncanakan dilaksanakan pada penelitian tahun berikutnya 


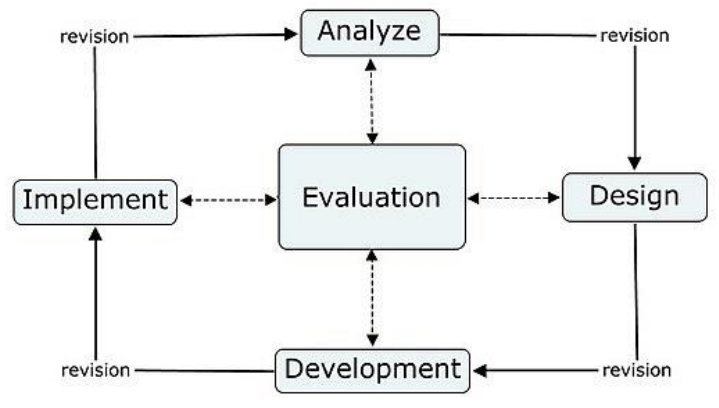

Gambar: Model Pengembangan ADDIE

Adapun penjelasan mengenai setiap tahap di atas adalah sebagai berikut:

1. Tahap Analysis

Pada tahap ini peneliti menganalisis kebutuhan pengembangan materi ajar berupa video YouTube atau non-cetak pada mata kuliah Bahasa Inggris untuk mahasiswa di luar prodi bahasa Inggris FKIP Universitas Jambi yang dikaitkan dengan kurikulum serta karakteristik peserta didik. Pada tahap ini juga dilakukan penyebaran angket pada mahasiswa yang telah mengontrak mata kuliah Bahasa Inggris yang bertujuan untuk menggali kebutuhan yang seperti apa yang mereka butuhkan dalam pembelajaran Bahasa Inggris berkaca dari pengalaman mereka ketika mengambil mata kuliah tersebut.

2. Tahap Design

Pada tahap ini tim peneliti menentukan tim pengembang seperti Validator ahli. Kemudian pada tahap ini juga dilakukan penyusunan jadwal pengembangan. Melalui jadwal yang telah disepakai, semua anggota tim berkomitmen menyelesaikan tugasnya masing-masing tepat waktu. Selanjutnya memilih dan menentukan cakupan, struktur dan urutan materi dimana sebelumnya sudah terseleksi dengan baik melalui metode analisis isi.

Diakhir tahap design ini akan diperoleh prototipe produk.

3. Tahap Development

Prototipe yang telah dibuat membutuhkan input perbaikan baik secara konseptual maupun praktikal. Di sinilah peran dari validator atau ahli. Kemudian ada juga validasi praktisi yang akan dilakukan oleh dosen lain untuk mendapat masukan dalam perspektif praktis.

\section{Data dan Sumber Data}

Data pada penelitian ini mencakup: (1) proses pengembangan materi ajar yang meliputi hasil refleksi proses pembelajaran mata kuliah Bahasa inggris, dokumentasi, dan hasil angket kebutuhan mahasiswa; (2) hasil wawancara pada uji coba terbatas; (3) hasil observasi keterlaksanaan materi ajar; (4) hasil analisa materi ajar Bahasa Inggris sebelumnya; (5)hasil observasi aktivitas mahasiswa, (6) hasil angket respon mahasiswa terhadap materi ajar yang dikembangkan, (7) hasil penilaian dari tim ahli validasi mengenai kualitas materi ajar yang dikembangkan.

\section{Tehnik Pengumpulan Data}

Istrument yang dipakai untuk mengumpulkan data adalah sebagai berikut:

1) Dokumentasi. dokumentasi digunakan untuk mempelajari kurikulum Bahasa Inggris. 
2) Angket. Angket digunakan untuk menganalisis kebutuhan mahasiswa akan materi ajar Bahasa Inggris dan respon mahasiswa terhadap bahan atau materi ajar yang dikembangkan, serta untuk mengetahui kelayakan bahan ajar yang dikembangkan yang didapat melalui hasil penilaian dari tim ahli validasi (validator).

3) Pedoman wawancara. wawancara digunakan untuk mengetahui respon mahasiswa terhadap bahan ajar yang dikembangkan. Sedangkan observasi digunakan untuk mendapatkan gambaran mengenai pelaksanaan proses pengembangan bahan ajar, keterlaksanaan bahan ajar, dan aktivitas mahasiswa di kelas pada saat bahan ajar diujicobakan.

\section{Tehnik Analisis Data}

Langkah yang ditempuh dalam analisis tersebut, yaitu (1) pengumpulan data; (2) pemilahan data; (3) pemaparan data; dan (4) pengambilan kesimpulan atau verifikasi. Setiap tahap dilakukan secara terstruktur dan terencana.

Data yang telah dikumpulkan selanjutnya dianalisis dan dikelompokkan kedalam tiga bagian, yakni (1) data analisis kebutuhan materi ajar Bahasa Inggris yang didapatkan dari angket untuk mahasiswa, (2) data dari hasil wawancara dan keterlaksanaan materi ajar berupa video YouTube atau non-cetak pada mata kuliah Bahasa Inggris untuk mahasiswa di luar prodi bahasa Inggris FKIP Universitas Jambi pada kelas terbatas (hasil observasi dan angket respon mahasiswa terhadap proses pembelajaran dengan bahan ajar yang dikembangkan), (3) data dari validasi dari tim ahli yang terdiri dari dosen ahli dan ahli disain visual. Selanjutnya semua data yang diperoleh dari hasil angket untuk mahasiswa, wawancara, observasi, dan angket validasi dianalisis secara kuantitatif dan kualitatif.

Untuk penilaian validasi oleh para ahli yaitu ahli materi dan ahli media dengan menggunakan skala penilaian dibawah ini.

Tabel 1. Kategori Skala Linkert

\begin{tabular}{|c|l|}
\hline Skor Nilai & \multicolumn{1}{c|}{ Interpretasi } \\
\hline 4 & Sangat Layak ( SL) \\
\hline 3 & Layak (L) \\
\hline 2 & Cukup Layak (CL) \\
\hline 1 & Kurang Layak (KL) \\
\hline
\end{tabular}

Tabel Pedoman Hasil Konversi Data Kriteria Penilaian Ideal yang diambil dari Kriteria Penilaian Ideal (Sukardjo, $2008: 53$ )

\begin{tabular}{|l|l|l|}
\hline NO & Rentang Skor & Kategori Kualitas \\
\hline 4 & $\mathrm{X}>3,4$ & Sangat Layak ( SL) \\
\hline 3 & $2,8<\mathrm{X} \leq 3,4$ & Layak (L) \\
\hline 2 & $2,2<\mathrm{X} \leq 2,8$ & Cukup Layak (CL) \\
\hline 1 & $1,6<\mathrm{X} \leq 2,2$ & Kurang Layak (KL) \\
\hline
\end{tabular}

\section{HASIL DAN PEMBAHASAN}

\section{Kebutuhan Mahasiswa Mata Kuliah Bahasa Inggris di Luar Program Studi Bahasa Inggris Fkip Unja}

Untuk mengetahui kebutuhan mahasiswa dalam mata kuliah Bahasa Inggris di luar prody Bahasa Inggris, peneliti telah melakukan penyebaran angket kuesioner kepada mahasiswa 
yang mengontrak mata kuliah Bahasa inggris yang diajar oleh peneliti. Angket ini disebarkan secara online kepada 35 mahasiswa yang menjadi responden. 35 mahasiswa tersebut berasal dari 1 kelas yang ada di Fakultas Ekonomi Unja.

Angket berupa kuesioner tersebut berisi 12 pertanyaan. 'semua informasi yang didapatkan akan sangat berguna dalam memutuskan langkah penelitian selanjutnya. Sebagai contoh dari angket kuesioner tersebut peneliti mendapatkan respon dari mahasiswa mengenai Apakah penyajian materi via Youtube bisa membantu Anda memahami materi yang ada di buku? dari tiga opsi jawaban " ya, tidak dan kadang-kadang", $75 \%$ yang menjawab "ya" , $25 \%$ yang menjawab "kadang-kadang", dan $0 \%$ yang menjawab "tidak". dari persentase itu, dapatlah disimpulkan bahwa penyajian materi melalui Youtube dapat membantu siswa dalam memahami materi yang ada di buku. hal ini juga terlihat dari tidak adanya mahasiswa sebagai responden yang menjawab option "tidak". Ini adalah salah satu pemacu peneliti untuk bisa menyajikan materi dengan memanfaatkan media YouTube. Untuk lebih jelasnya, berikut peneliti tampilkan summary atau ringkasan hasil dari penyebaran untuk mahasiswa di luar prody Bahasa Inggris.

Berapa sering Anda menonton YouTube?

35 tanggapan

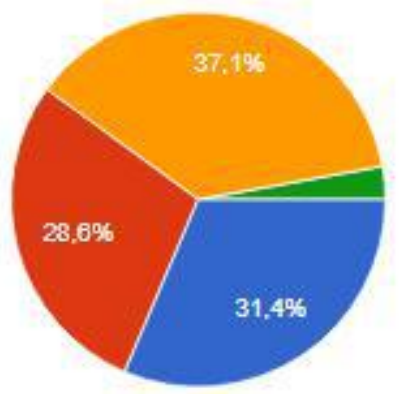

Setiap hari

Hampir tiap har

1 sampai 3 kali seminggu

Kadang kadang

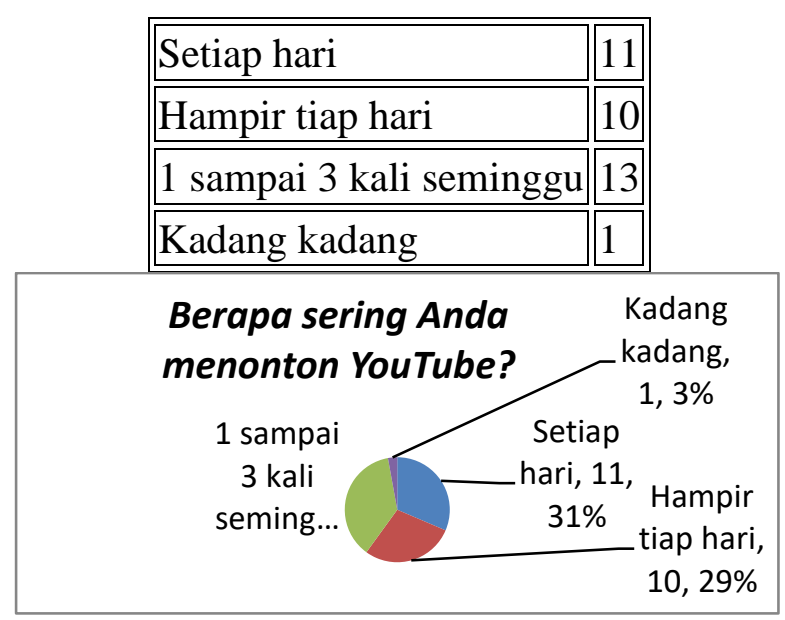

Dari jawaban di atas, persentase yang menjawab 1 sampai 3 kali seminggu lebih banyak daripada pilihan lainnya. Namun kalau digabung pilihan 'tiap hari' dan 'hampir setiap hari', maka pilihan inilah yang menduduki presentase terbanyak. Jadi dari temuan ini, dapat ditarik kesimpulan bahwa mereka Media YouTube sangat diminati terlihat dari presentase mereka menontonnya. 
Pernahkah Anda belajar dengan dosen lain yang materinya disajikan langsung oleh dosen bersangkutan melalui Youtube?35 tanggapan

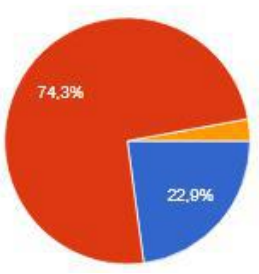

- Pernah

- Tidak pernah

Sejauh ini baru dosen b. Inggris

\begin{tabular}{|l|l|}
\hline Pernah & 8 \\
\hline Tidak pernah & 26 \\
\hline Sejauh ini baru dosen b. Inggris & 1 \\
\hline
\end{tabular}

Dari data tersebut, terlihat Penggunaan Media Youtube dalam pembelajaran yang dibuat sendiri oleh dosen di Universitas Jambi, terutama yang pernah mengajar mahasiswa yang menjadi partisipan dalam penelitian ini, masih sangat sedikit sekali. Padahal Media ini punya peluang besar dalam menyajikan materi yang tidak terikat oleh kjarak dan waktu.

Apakah penyajian materi via Youtube bisa membantu Anda memahami materi yang ada di buku?35 tanggapan

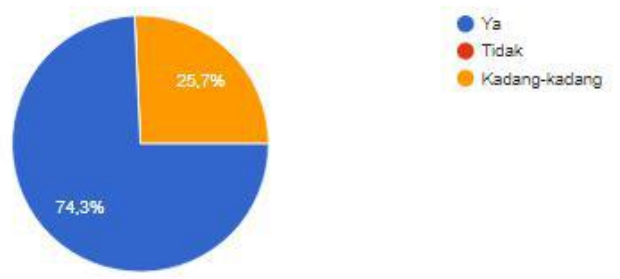

\begin{tabular}{|l|l|}
\hline Ya & 26 \\
\hline Tidak & 0 \\
\hline Kadang-kadang & 9 \\
\hline
\end{tabular}

Dari data yang didapat, sebesar $74 \%$ partisipan menjawab bahwa penyajian materi via youtube bisa membantu mereka memahami materi yang ada di buku.

Alasannya:30 tanggapan

Berikut adalah beberapa contoh tanggapan yang diberikan. Untuk versi lengkapnya bisa dilihat di lampiran.

- Karena akan lebih mudah saya pahami saat saya menonton video di youtube

- Karena video penyajian pelajaran diyoutube bisa ditonton berulang-ulang, sehingga saat kita tidak memahami materi dalam sekali tonton kita tinggal mengulang lagi videonya sampai kita paham 
Apakah tanpa penjelasan materi di Youtube, Anda bisa juga dengan mudah memahami sendiri semua materi yang ada di buku?35 tanggapan
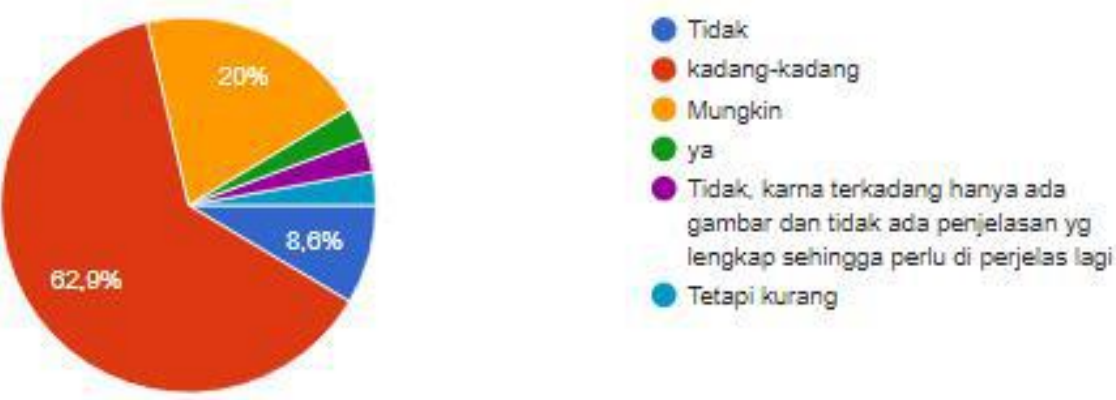

\begin{tabular}{|l||l||}
\hline Tidak & 3 \\
\hline kadang-kadang & 22 \\
\hline \hline Mungkin & 7 \\
\hline Ya & 1 \\
\hline $\begin{array}{l}\text { Tidak, karna terkadang hanya ada gambar dan tidak ada penjelasan yg lengkap sehingga } \\
\text { perlu di perjelas lagi }\end{array}$ & 1 \\
\hline Tetapi kurang & 1 \\
\hline
\end{tabular}

Mana yang lebih menarik untuk ditonton dan dipahami?35 tanggapan

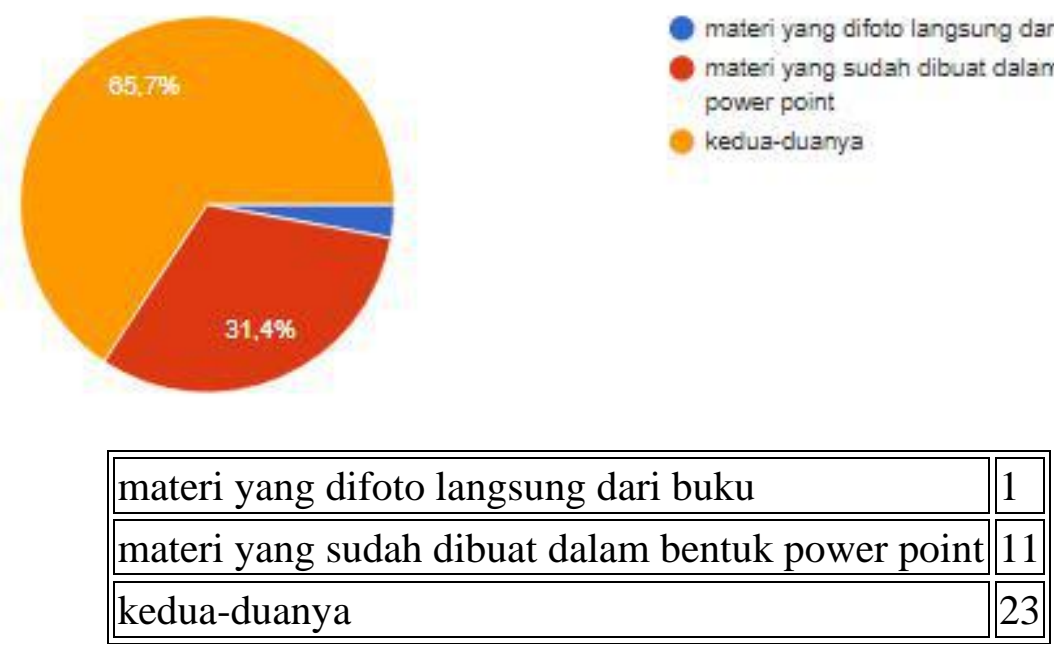


Berapa menit sebaiknya penyajian materi bahasa Inggris di YouTube? 35 tanggapan

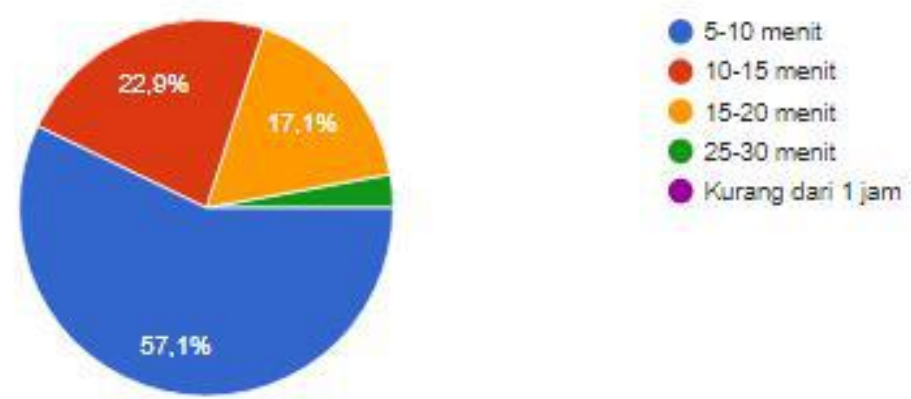

\begin{tabular}{|l||l|}
\hline $5-10$ menit & 20 \\
\hline $10-15$ menit & 8 \\
\hline $15-20$ menit & 6 \\
\hline $25-30$ menit & 1 \\
\hline \hline Kurang dari 1 jam & 0 \\
\hline
\end{tabular}

Apakah perlu menambah sound effect atau musik ketika penyajian materi di YouTube? 35 tanggapan
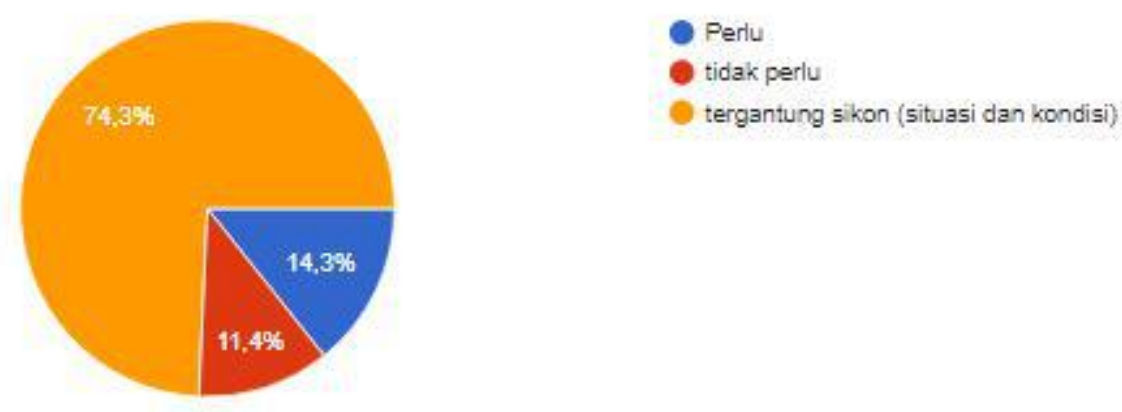

\begin{tabular}{|l|l|}
\hline Perlu & 5 \\
\hline \hline tidak perlu & 4 \\
\hline \hline tergantung sikon (situasi dan kondisi) & 26 \\
\hline
\end{tabular}

Materi apa yang sebaiknya lebih banyak diberikan?(boleh jawab lebih dari satu) 35 tanggapan

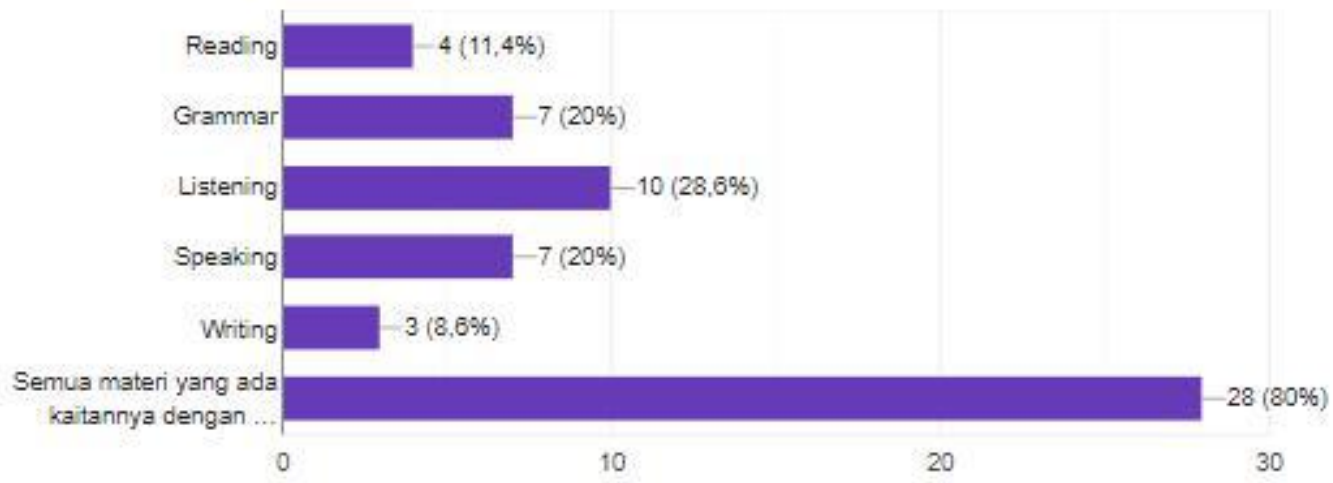




\begin{tabular}{|l|l|}
\hline \multicolumn{1}{|c|}{ Nilai } & Jumlah \\
\hline Reading & 4 \\
\hline Grammar & 7 \\
\hline Listening & 10 \\
\hline Speaking & 7 \\
\hline Writing & 3 \\
\hline Semua materi yang ada kaitannya dengan ... & 28 \\
\hline
\end{tabular}

Dari data yang sudah didapat di atas, akan menjadi masukan dalam menghasilkan video pembelajaran Bahasa Inggris via Youtube yang lebih baik dan menarik guna menunjang pembelajaran Mata Kuliah Bahasa Inggris untuk mahasiswa di luar bahasa Inggris itu sendiri

\section{Kelayakan Produk}

\section{Hasil Validasi Ahli Materi}

\begin{tabular}{|c|c|c|c|c|c|}
\hline \multirow[t]{2}{*}{ No } & \multirow[t]{2}{*}{ Komponen } & \multicolumn{4}{|c|}{ Skala Penilaian } \\
\hline & & 1 & 2 & 3 & 4 \\
\hline 1. & Kebenaran materi sudah tepat & & & & 2 \\
\hline 2. & Kelengkapan materi & & & & 2 \\
\hline 3. & Materi disusun secara berurutan & & & 1 & 1 \\
\hline 4. & Mudah dipahami secara keseluruhan & & & 1 & 1 \\
\hline 5. & $\begin{array}{l}\text { Penjelasan materi disampaikan dengan Bahasa yang } \\
\text { jelas }\end{array}$ & & & 1 & 1 \\
\hline 6. & $\begin{array}{l}\text { Materi yang disajikan merangsang keingintahuan } \\
\text { peserta didik }\end{array}$ & & & & 2 \\
\hline 7. & Ilustrasi musik mendukung saat pembelajaran & & & & 2 \\
\hline \multicolumn{2}{|c|}{ Jumlah Skor } & 0 & 0 & 9 & 44 \\
\hline \multicolumn{2}{|c|}{ Skor Total } & \multicolumn{4}{|l|}{53} \\
\hline \multicolumn{2}{|c|}{ Rerata } & \multicolumn{4}{|l|}{3,8} \\
\hline \multicolumn{2}{|c|}{ Kesimpulan } & \multicolumn{4}{|l|}{ San } \\
\hline
\end{tabular}

Nilai rata-rata diperoleh dengan membagi skor total dengan jumlah item komponen dikali 2 validator

Nilai rata-rata $=$ Skor Total : (Jumlah item komponen $\mathrm{x} 2$ validator)

$$
\begin{aligned}
& =53:(7 \times 2) \\
& =3,8(\text { kategori sangat layak })
\end{aligned}
$$

\section{Hasil Validasi Media}

\begin{tabular}{|l|l|c|c|c|c|}
\hline \multicolumn{1}{|c|}{ Komponen } & \multicolumn{4}{c|}{ Skala Penilaian } \\
\cline { 4 - 6 } & & $\mathbf{1}$ & $\mathbf{2}$ & $\mathbf{3}$ & $\mathbf{4}$ \\
\hline 1. & Tampilan Visual & & & & $\mathbf{2}$ \\
\hline 2. & Kualitas audio & & & & 2 \\
\hline 3. & Pembukaan Video yang tidak bertele-tele & & & 1 & 1 \\
\hline 4. & Animasi power point di video & & & 1 & 1 \\
\hline 5. & Durasi video aman ditonton & & & & 2 \\
\hline 6. & Penggunaan Sound Effect & & & 1 & 1 \\
\hline 7. & Penggunaan Sticker artistik & & & 1 & 1 \\
\hline
\end{tabular}




\begin{tabular}{|l|l|l|l|l|}
\hline Jumlah Skor & 0 & 0 & 12 & 40 \\
\hline Skor Total & $\mathbf{5 2}$ & & \\
\hline Rerata & $\mathbf{3 , 7}$ \\
\hline Kesimpulan & Sangat Layak \\
\hline
\end{tabular}

Nilai rata-rata diperoleh dengan membagi skor total dengan jumlah item komponen dikali 2 validator

Nilai rata-rata $=$ Skor Total : (Jumlah item komponen $\mathrm{x} 2$ validator $)$

$$
\begin{aligned}
& =52:(7 \times 2) \\
& =3,7 \text { (kategori sangat layak })
\end{aligned}
$$

\section{Materi Video Pembelajaran}

Pada bagian ini akan sajikan materi video pembelajaran yang diunggah ke YouTube. Materi di video ini diambil dari materi yang dipakai dalam perkuliahan tatap muka atau off line meeting. Terdapat 14 video yang sudah dibuat untuk 14 pertemuan karena 2 pertemuan lainnya diperuntukan untuk ujian tengah semester (UTS) dan ujian akhir Semester (UAS).

1. Subjek dalam Bahasa Inggris

2. Tobe dalam Bahasa Inggris

3. I am Doing (Present Continous Tense)

4. Cara Menggabungkan Verb 1 dengan -ing

5. I watched/Cleaned, etc. (Simple Past)

6. Pronoun

7. Adjective Clause

8. Noun Clause

9. Reading "How do you read"

10. Writing and Reading "Aphostrophe"

11. Writing and Reading "Describing Our Lives"

12. Listening "First and Last Names"

13. Listening "Time"

14. Speaking "So, Tell me about your family"

\section{Luaran yang Dicapai}

Adapun luaran yang dicapai hingga saat ini adalah telah diseminarkannya hasil penelitian di seminar inernasional GDIC yang diselanggarakan oleh LPPM Unja pada tanggal 2 dan 3 Oktober 2020 dan juga pada seminar nasional V penelitian FKIP pada tanggal 24 November 2020. Selain itu, luaran berupa protoptype video pembelajaran yang diunggah ke Youtube juga sudah terlaksana. Artinya pencapaian ini merupakan realisasi dari rencana target capaian yang tertuang dalam proposal penelitian ini.

\section{KESIMPULAN DAN SARAN}

Dari pemaparan di bab sebelumnya, maka dapat disimpulkan bahwa:

1. Pembelajaran Bahasa Inggris di luar Prody Bahasa Inggris dengan menggunakan video Youtube dalam menjelaskan materi kuliah mendapat sambutan positif dari mahasiswa. Hal itu terlihat dari respon yang mereka berikan.

2. Pembuatan video pembelajaran yang akan diupload ke YouTube perlu didesain sebaik mungkin baik tampilan, durasi dan lain sebagainya. Semua hal tersebut mengacu pada respon mahasiswa yang sudah didapatkan dalam penyebaran kuesioner sebelumnya. 
Disarankan kepada peneliti yang berminat pada kajian yang sama untuk terus melakukan penelitian yang serumpun agar mutu pembelajaran mata kuliah terutama Bahasa Inggris untuk mahasiswa di luar prody Bahasa Inggris semakin baik.

\section{DAFTAR PUSTAKA}

Arniati. 2017. Pengembangan Modul Berbasis Pengajaran dan Pembelajaran Kontekstual (Contextual Teaching and Learning) Pada Mata Pelajaran Ipa Kelas V Sekolah Dasar. Jurnal PENAMAS Volume 30, Nomor 2, Juli-September 2017, Halaman $i-i v$

Borg, W. R. \& Gall, M. D. 1983. Educational Research: An Introduction. Boston, New York, and London: Pearson Education.

Danuhari.2014. Pengembangan Modul Matematika dengan Pendekatan Kontekstual untuk menfasilitasi Kemendarian Belajar Siswa SD/MI. Jurnal Pendidikan Dasar Islam AlBidayah, Volume 6, no 1, Juni 2014;ISSN 208034

Fuldiaratman dan Harizon. 2015. Pengembangam E-Modul berbasis flip bookmaker sebagai Sumber Belajar pada Mata Kuliah Psikologi Pendidikan untuk mahasiswa Pendidikan Kimia PGMIPAU FKIP Universitas Jambi. Penelitian. Jambi: Universitas Jambi

Harmer, J. (2001). The practice of English language teaching, $3^{\text {rd }}$ ed. London: Longman Ismaya, Bambang. 2015. Pengelolaan Pendidikan. Bandung: PT Refika Aditama

Latief, Mohammad Adnan. 2009. Penelitian Pengembangan. Malang: Universitas Negeri Malang

Latief, Mohammad Adnan. 2014. Tanya Jawab Metode Penelitian Pembelajaran Bahasa. Malang: UNIversitas Negeri Malang

Masbirorotni dan Hustarna. 2016. Pengembangan Prototype Bahan Ajar Listening for General Proposes Berbasis Video. Penelitian. Jambi: Universitas Jambi

Mulyasa.2013. Pengembangan dan Implementasi Kurikulum 2013. Bandung: Penerbit PT Remaja Rosdakarya.

Putri, Hilda. 2017. Pengembangan Modul Berbasis Pendekatan Kontekstual Untuk Pembelajaran Menulis Teks Anekdot. Jurnal Pendidikan Bahasa dan Sastra, Volume 17, Nomor 2, Oktober 2017, hlm. 241-252

Rusdi. 2018. Penelitian Desain Pengembangan Kependidikan. Depok: PT RajaGrafindo

Sadjati, Ida Malati. 2012. Pengembangan Bahan Ajar. Jakarta: Universitas Terbuka

Suryana, Asep dan Suryadi. 2009. Modul Pengelolaan Pendidikan. Jakarta:Direktorat Jenderal Pendidikan Islam

Tim BELMAWA DIKTI. 2014. Buku Panduan Kurikulum Pendidikan Tinggi. Jakarta:Kementerian Pendidikan dan Kebudayaan

Volya, Duti dan Arif, Nely .2017. Pengembangan Materi Ajar English Phonology Berbasis Pendekatan Kontekstual pada Program Studi Pendidikan Bahasa Inggris Universitas Jambi. Penelitian yang tidak dipublikasikan. Jambi: Universitas Jambi

Lampiran: Bukti luaran 'Produk Video Pembelajaran YouTube”

1. Pembuatan Materi dengan Power Point 


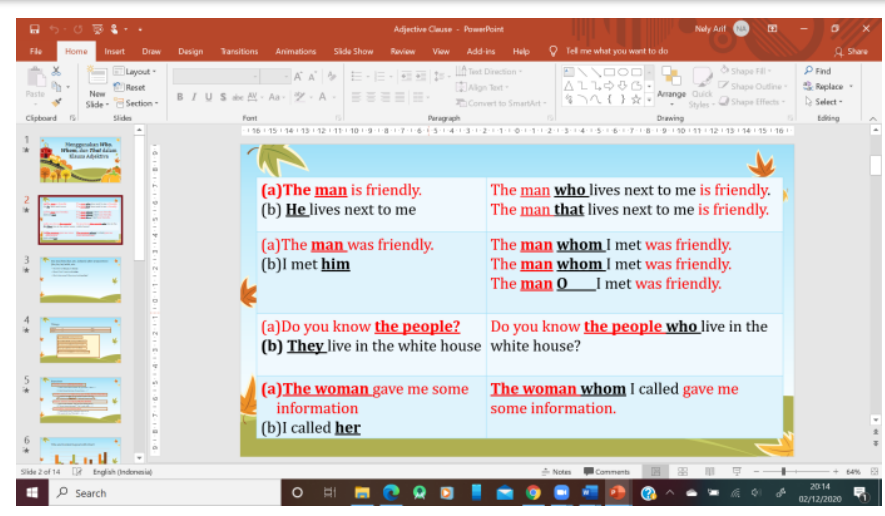

2. Materi di Power Point diedit dengan Kinemaster

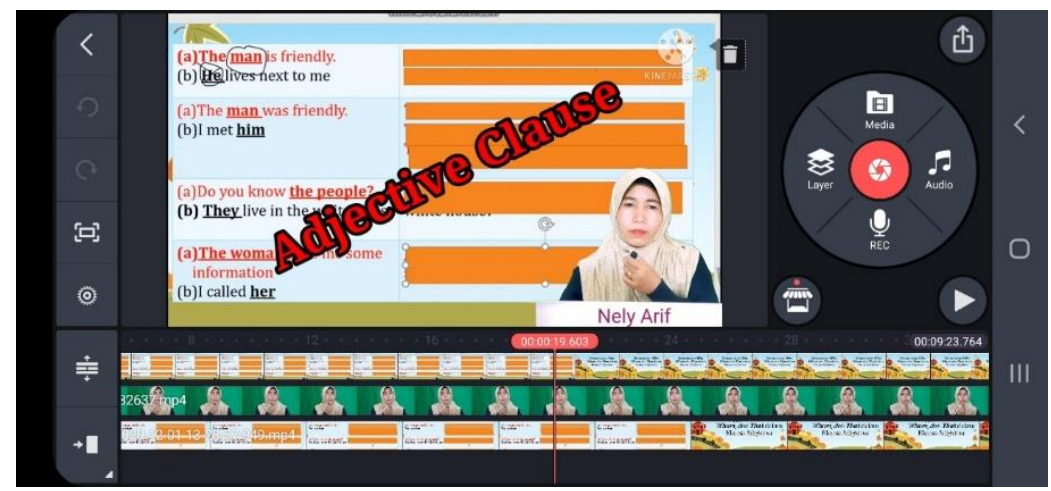

3. Video yang telah diedit diupload ke YouTube

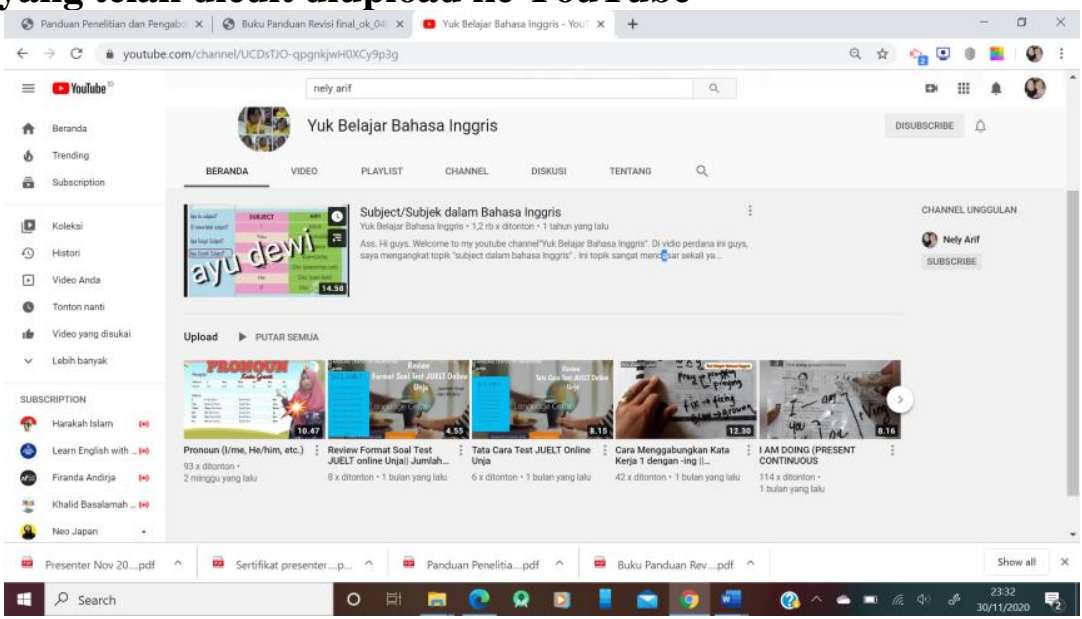

